\title{
PENANGGULANGAN KRISIS AIR BERSIH DI DESA SERIWE KECAMATAN JEROWARU KABUPATEN LOMBOK TIMUR
}

\author{
Baiq Tahyatul Wafi'), Armin Subhani2) \\ 1,2Program Studi Pendidikan Geografi, Universitas Hamzanwadi \\ Email: armin@hamzanwadi.ac.id
}

\begin{abstract}
Abstrak
Penelitian ini bertujuan untuk mengetahui bagaimana penanggulangan krisis air bersih di Desa Seriwe Kecamatan Jerowaru. Seiring dengan pertambahan jumlah penduduk Desa Seriwe, maka permintaan air bersih akan terus meningkat. Belum optimalnya pelayanan PDAM di Desa Seriwe membuat pemenuhan air bersih menjadi terganggu. Jenis penelitian ini adalah deskriptif kualitatif. Untuk memperoleh data dilapangan dilakukan dengan teknik observasi, dokumentasi, dan wawancara mendalam. Teknik sampel menggunakan sampel purposive sampling, dengan subjek penelitian terdiri dari pemerintah Desa Seriwe dan masyarakat Desa Seriwe yang merasakan dampak langsung krisis air bersih. Setelah data terkumpul, data kemudian dianalisis dengan teknik analisis kualitatif, interactive model. Berdasarkan hasil analisis data, dapat disimpulkan bahwa usaha penaggulangan krisis air bersih yang dilakukan oleh pihak pemerintah yaitu dengan menyediakan bak penampungan air bersih yang merupakan bantuan dari BNPB. Sementara itu, usaha yang dilakukan oleh masyarakat untuk menanggulangi krisis air bersih yaitu dengan membeli air bersubsidi dari PDAM yang dijual menggunakan mobil tangki air.
\end{abstract}

Kata Kunci: Penanggulangan, Kerisis air bersih

\section{PENDAHULUAN}

Ada beberapa daerah di Indonesia mengalami krisis air bersih yang tentunya membutuhkan perhatian serius dari semua pihak. Khususnya di Provinsi Nusa Tenggara Barat (NTB), terdapat beberapa titik daerah yang mengalami krisis air bersih. Salah satunya adalah di Desa Seriwe Kecamatan Jerowaru Kabupaten Lombok Timur. Sudah tidak terhitung lamanya krisis air bersih sudah melanda warga Desa
Seriwe. Segenap warga mencoba bertahan ditengah suasana kekeringan tersebut.

Desa Seriwe merupakan pecahan dari hasil pemekaran Desa Pemongkong dimana desa ini berkecamatan di Kecamatan Jerowaru. Desa seriwe terletak $8 \mathrm{~km}$ dari Desa Pemongkong Kecamatan Jerowaru Kabupaten Lombok Timur, berjarak $45 \mathrm{~km}$ dari Ibu kota Kabupaten Lombok Timur serta $76 \mathrm{~km}$ dari Ibu kota Provinsi Nusa Tenggara Barat. 
Desa Seriwe terdiri dari beberapa dusun, antara lain Dusun Kaliantan, Dusun Seriwe, Dusun Temodo, dan dua Dusun persiapan yaitu Dusun Semerang dan Dusun Persetapuk.

Air bersih merupakan kebutuhan pokok bagi kehidupan manusia. Kebutuhan air yang di maksud adalah kebutuhan air yang digunakan untuk menunjang segala kegiatan manusia, meliputi air bersih domestik, non domestik maupun air irigasi. Kebutuhan akan air secara umum dikategorikan dalam kebutuhan air domestik dan non domestik. Kebutuhan domestik adalah kebutuhan air yang yang digunakan untuk keperluan rumah tangga yaitu untuk keperluan minum, masak, mandi, mencuci pakaian serta keperluan lainnya. Kebutuhan air domestik sangat di tentukan oleh jumlah penduduk dan konsumsi perkapita. Sedangkan kebutuhan air non domestik di gunakan untuk kantor, tempat ibadah, dan lain-lain (Kodoatie, 2008).

Secara teoritis, krisis air bersih dapat dipahami sebagai kurangnya cadangan air bersih di suatu wilayah sehingga tidak cukup untuk memenuhi berbagai kebutuhan manusia. Adapun dampak krisis air bersih cukup signifikan bagi masyarakat, diantaranya akan berdampak bagi kesehatan yaitu timbulnya berbagai macam penyakit, serta secara ekonomi akan berdampak pada sulitnya mendapatkan air bersih terutama bagi rakyat miskin (Setiawan, 2013).

Kebutuhan manusia akan air bersih tentu saja bukan saja persoalan kuantitasnya atau untuk menjawab pertanyaan berapa jumlah kebutuhannya, namun juga terkait dengann kualitasnya, untuk menjawab apakah air tersebut layak dikonsumsi atau tidak. Sebagaimana diungkapakn Sanim, (2011) bahwa pemanfaatan dan pengandalian sumberdaya air meliputi kualitas dan kuantitas air. Kualitas air menjadi titik penting dalam pemanfaatan karena pemanfaatan sumberdaya air tidak hanya bergantung kepada seberapa besar jumlah air yang diperoleh untuk mencukupi kebutuhan, namun juga kualitas yang sesuai dengan kebutuhan manusia.

\section{METODE PENELITIAN}

Penelitian ini merupakan penelitian deskriptif dengan 
pendekatan kualitatif. Melalui dan keruh disebabakan lokasinya yang penelitian ini akan berupaya diungkap bagaimana proses penanggulangan krisis air bersih dengan menyajikan data dengan deskripsi (penggambaran) fenomena yang mendalam. Adapun data dilapangan dikumpulkan dengan menggunakan teknik wawancara mendalam (indepth interview), teknik observasi, dan teknik dokumentasi. Penentuan subjek penelitian menggunakan purposive sampling. Sebagai subjek dalam penelitian ini yaitu dari Pemerintah Desa Seriwe dan masyarakat Desa Seriwe yang merasakan dampak langsung krisis air bersih.

\section{HASIL DAN PEMBAHASAN}

Penanggulangan krisis air oleh masyarakat antara lain dapat dilihat dari upaya yang dilakukan dalam memperoleh air bersih tersebut, antara lain:

\section{1) Membuat sumur gali tradisional}

Usaha lainnya yang dilakukan masyarakat adalah membuat sumur gali tradisional, akan tetapi air yang terdapat dalam sumur tersebut tidak dapat dimanfaatkan untuk minum dan masak, karena air sumur tersebut asin 


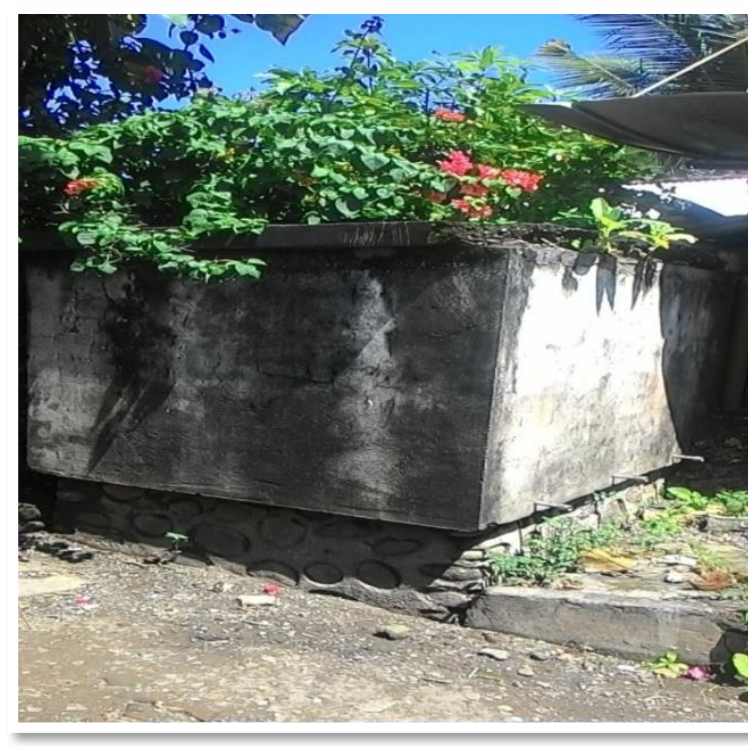

Gambar 2. Bak penampungan air bersih hasil swadaya masyarakat

(Sumber: dokumentasi peneliti, 2017)

3) Mengambil air bersih dari sumur

\section{Petutu di Desa Jerowaru}

Kebutuhan air bersih bagi masyarakat di Desa Seriwe cukup besar. Hal ini dapat dilihat dari air bersih yang diperoleh dari Petutu belum bisa mencukupi kebutuhan masyarakat. Petutu adalah sebuah sumur yang terletak di luar Desa Seriwe, yaitu tepatnya berada di tengah-tengah Desa Jerowaru yang airnya jernih, tidak berbau dan tidak asin sehingga dapat dikonsumsi oleh masyarakat seperti untuk minum, memasak, mandi, dan mencuci. Dari segi kuantitas, air petutu Desa Sriwe bisa dimanfaatkan sekitar 500 liter/hari oleh masyarakat. Akan tetapi penggunaan air petutu menurun setiap tahunnya dikarenakan letak air petutu yang cukup jauh dari Desa Seriwe (sekitar $15 \mathrm{~km}$ ).

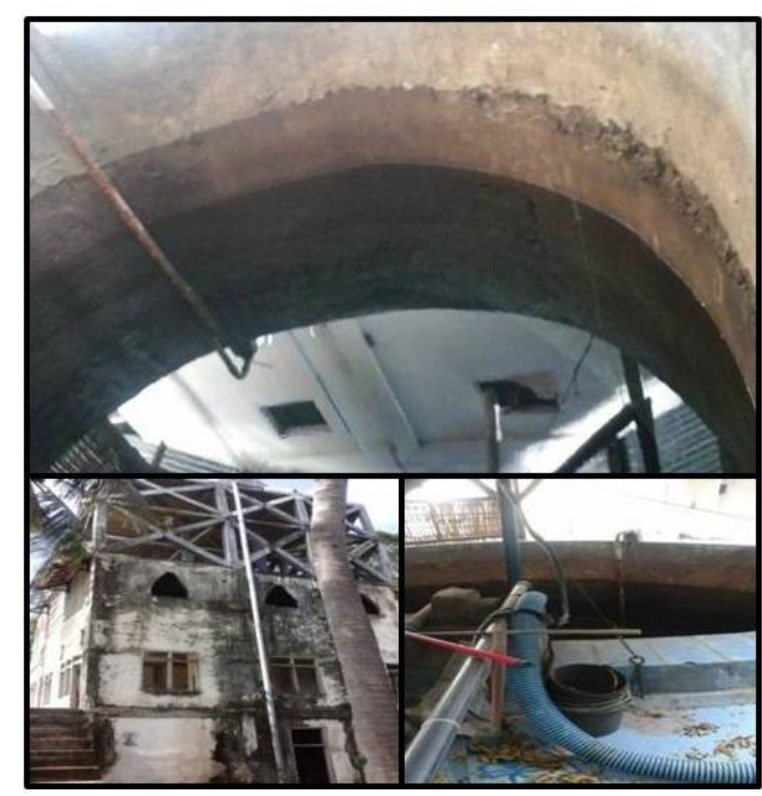

Gambar 3. Sumur Petutu di Desa Jerowaru (Sumber : dokumentasi peneliti, 2017)

4) Mengambil air dari sumber air bersih di Desa Jor

Selain dari sumur Petutu di Desa Jerowaru, masyarakat Desa Sriwe juga mengambil air bersih dari sumber air bersih yang terdapat di Desa Jor. Biasanya, warga mengambil air bersih secara individu menggunakan sepeda motor dengan jarak tempuh $10 \mathrm{~km}$ dari Desa Sriwe menuju Desa Jor dengan ukuran rata-rata drijen 30 liter. 
5) Membeli air bersih di PDAM maupun air galon isi ulang

Untuk memeperoleh air bersih, sebagian besar masyarakat Desa Seriwe membeli air bersih secara langsung dari PDAM maupun membeli air gallon isi ulang. Secara individu biasanya warga membeli air bersih dengan harga Rp 3000/5 liter. Untuk membeli air bersih di PDAM, mayoritas warga secara individu menggunakan ember yang berukuran 5liter.

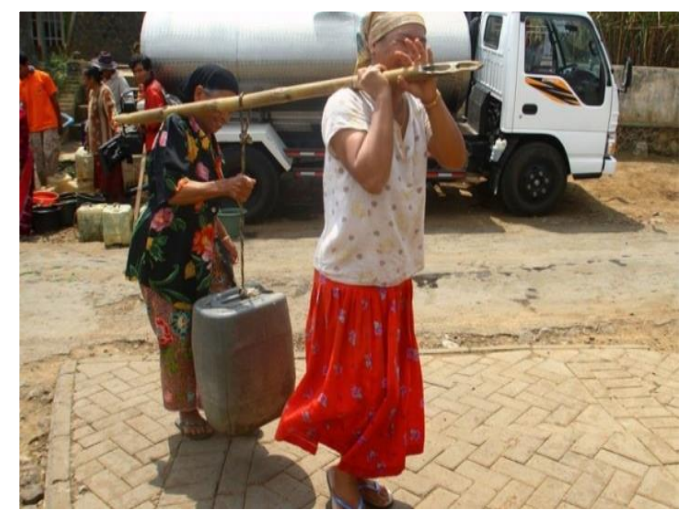

Gambar 4. Warga membeli air dari tangki air bersih PDAM

(Sumber : dokumentasi peneliti, 2017)

Sedangkan beberapa warga diantaranya membeli air bersih secara berkelompok, dengan harga Rp150.000/tanki. Sementara itu, selain upaya penanggulangan krisis air bersih yang terjadi di Desa Seriwe dilakukan oleh masyarakat, juga dilakukan oleh pemerintah.

\begin{abstract}
Adapun peran pemerintah dalam penanggulangan krisis air
\end{abstract} bersih tersebut antara lain:

1) Menyediakan fasilitas berupa bak penampungan air bersih

Fasilitas ini merupakan sumbangan dari Badan Nasional Penanggulangan Bencana (BNPB). Bak penampungan air tersebut ditempatkan di depan kantor desa, biasanya dimanfaatkan pada saat musim hujan untuk menampung air hujan. Selain itu bak penampungan itu juga dimanfaatkan untuk kegiatan kemasyarakatan seperti kegiatan kematian dan perkawinan. Bak penampungan yang tersedia dari pemerintah hanya satu unit. Hal ini dikarenakan program pengadaan yang diajukan belum mendapat respon dari pemerintah pusat. 


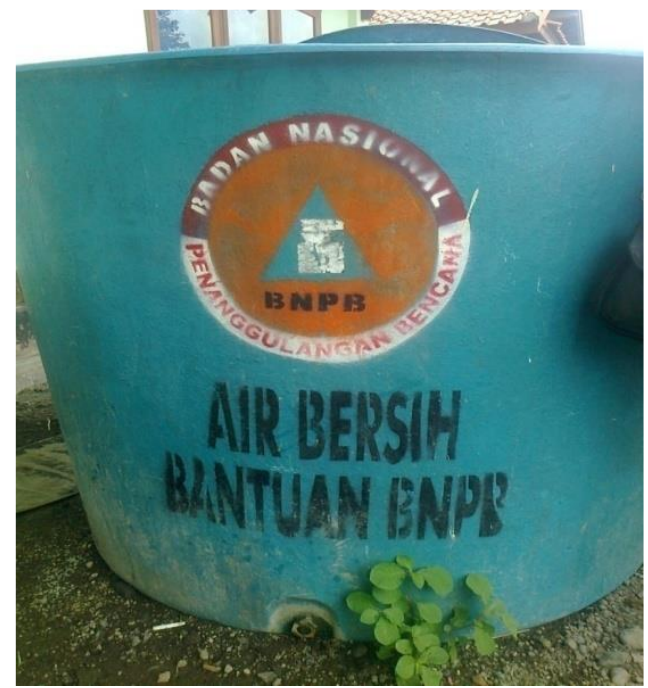

Gambar 5. Bak penampungan air bersih bantuan BNPB

(Sumber: dokumentasi peneliti, 2017)

2) Pengadaan perpipaan antar dusundusun yang berjauhan.

Pengadaan perpipaan yang dilakukan oleh pemerintah tersebut dialiri dari Desa Pemongkong. Namun demikian, program itu belum mampu mengatasi persoalan krisis air bersih di Desa Seriwe. Oleh karena itu pemerintah desa dan masyarakat harus mengumpulkan dana secara swadaya untuk mencapai keinginan mereka mewujudkan tersedianya perpipaan antar dusun-dusun di Desa Seriwe yang berjauhan, seperti Dusun Temodo, Dusun Kaliantan dan Dusun Seriwe.

3) Memfasilitasi air bersih bagi warga dari PDAM

Pemerintah desa bekerjasama dengan PDAM memfasilitasi warga air bersih yang dapat dibeli dari mobil-mobil tanki air bersih milik PDAM. Dengan keberadaan mobil-mobil tanki air bersih milik PDAM ini, masyarakat cukup terbantu untuk memenuhi kebutuhan mereka akan air bersih. Namun, air bersih yang diperoleh dengan membeli ini sifatnya hanya jangka pendek semata, warga desa Seriwe tidak mampu selamanya membeli air untuk segala kebutuhan hidupnya, mengingat kondisi ekonomi masayarakat yang relatif lemah.

\section{KESIMPULAN}

Berdasarkan hasil penelitian mengenai penanggulangan krisis air bersih di Desa Seriwe Kecamatan Jerowaru Kabupaten Lombok Timur dapat diambil beberapa kesimpulan, diantaranya penanggulangan krisis air bersih oleh masyarakat secara swadaya dilakukan dengan cara membuat sumur gali tradisional, membuat bak penampungan air bersih, mengambil air bersih dari sumur Petutu di Desa Jerowaru, mengambil air dari sumber air di Desa Jor, membeli air bersih di PDAM maupun membeli air galon isi ulang. Sementara upaya penanggulangan krisis air dari pihak pemerintah dapat 
dilihat dari beberapa upaya yang dilakukan antara lain menyediakan fasilitas berupa bak penampungan air bersih, pengadaan perpipaan antar dusun-dusun yang berjauhan, serta memfasilitasi air bersih bagi warga dari PDAM.

\section{DAFTAR PUSTAKA}

Arikunto, Suharsimi. (2006.

Prosedur Penelitian Suatu

Pendekatan Praktik.

Arsyad, S. (1989). Konservasi Tanah dan Air. Penerbit IPB: Bogor.

Danaryanto, et al. 2008. Manajemen Air Tanah Berbasis Cekungan Air Tanah.

Dinas Pertambangan dan Energi provinsi Jawa Tengah. (2004). Potensi Cekungan

Direktorat Pembinaan Pengusahaan Panas Bumi dan Pengelolaan Air Tanah, Direktorat Jendral Mineral, Batu Bara dan Panas Bumi, Departemen Energi dan Sumber Daya Mineral.

DitJen. Sumber Daya Air Dep. Kimpraswil. 2002. Pengelolaan Terpadu Sumber Daya Air dan Repormasi Kebijakan

Pengelolaan Sumber Daya Air.
Lokakarya Nasional tentang Pengelolaan Terpadu Sumberdaya Air. Kerja sama DitJen. Sumberdaya Air Dep. Kimpraswil dengan South Eeast Asia Technical Advisory Committe (SEATAC).

Haldien. 2011. Pengelolaan Air Bersih. Diunduh 6 Juni 2011. Iman, Ansori. 2004. Konsepsi Pengelolaan Sumber Daya Air Menurut UU No.7

Kodoatie, Robert J. (2008). Pengelolaan Sumberdaya Air Terpadu. Yogyakarta: Andi.

Sanim, B. (2011). Sumberdaya Air dan Kesejahteraan Publik. Bogor IPB Press. 